\title{
A Tania Franco Carvalhal, nuestro especial convivio...
}

El hilo no se ha roto, permanece suspendido, etéreo y misterioso, enhebrando insondables geografías que invisibles pero ciertas, ligan y entraman lo que ha sido hecho. Definen los "entre" y consolidan las proyecciones de todas las fronteras, geográficas o culturales, físicas o vitales.

Un hilo que entreteje y desovilla ecos, pasajes y todas esas "corrientes de aire" de que se ocupan los comparatistas. En un iluminador seminario en Tucumán hace una década, esa fue la certera respuesta que escuchamos de la Dra. Carvalhal a la consabida pregunta sobre la especificidad del ámbito. Nunca lo olvidamos.

El 10 de septiembre de 2006, Tania, la académica y la amiga, partió dejando su huella indeleble. Entusiasta y señera acción con que consustanció el espacio de los estudios de la literatura comparada en su Brasil natal y en Argentina.

Como con toda forma de genialidad, no va a ser fácil cubrir su ausencia y el prestigio que su destacada trayectoria y labor aportaba al ámbito del Comparatismo en este continente y el modo cómo lograba su interrelación con el mundo.

Pero la ausencia física no puede ni debe cancelar lo iniciado por la Dra. Carvalhal sino potenciar su presencia en nuestro destino académico. La imagen permanece activa en todos los que tuvimos el privilegio de aprender de su entusiasmo. El estímulo pujante de su palabra nos incita a continuar la senda emprendida.

No fue menor la relevancia de su presencia en la generación del El Centro de Estudios Comparados y de esta su revista: El hilo de la fábula, así como en muchas acciones emprendidas en el seno del mismo. En su homenaje recuperamos la palabra de sus colaboradores más cercanos e incluimos uno de sus últimos ensayos sobre el comparatismo en Brasil, publicado en versión francesa en una de las revistas más prestigiosa de Francia.

A la gran comparatista y amiga, chapeau! 